\title{
Enhancing the Value of Patents as Corporate Assets in South Africa: How can Artificial Intelligence (Al) Assist?
}

\section{P.E.R}

Pioneer in peer-reviewed, open access online law publications

Author

Lonias Ndlovu

Affiliation

University of Venda, Limpopo, South Africa

Email lonias.ndlovu@univen.ac.za

Date Submission

28 October 2020

Date Revised

1 May 2021

Date Accepted

2 May 2021

Date published

23 June 2021

\section{Editor Dr TV Warikandwa}

How to cite this article

Ndlovu L "Enhancing the Value of Patents as Corporate Assets in South Africa: How can Artificial Intelligence (AI) Assist?" PER / PELJ 2021(24) - DOI

http://dx.doi.org/10.17159/1727$3781 / 2021 / v 24$ i0a10736

\section{Copyright}

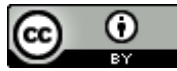

DOI

http://dx.doi.org/10.17159/17273781/2021/v24i0a10736

\begin{abstract}
Although the accounting definition of assets contemplates intangible, abstract assets such as those embodied in intellectual property (IP), South African company law largely views IP as a legal and not a business asset. This paper tentatively suggests an approach that uses artificial intelligence (Al) to mitigate weaknesses in the South African patent law relating to the absence of patent searches and examinations. It is hoped that using Al will enable the filing of quality patents that satisfy the prescribed patentability criteria. High-quality patents will allow companies to accumulate patents as corporate assets. The approach is based on the algorithmic use of Al technologies such as machine learning, natural language processing, deep learning alongside the Internet of Things, and IP analytics to strengthen South Africa's IP system and create asset value for corporations. The paper recommends using the proposed Al technologies by companies and the Patents Office to enable the filing of high-quality patents, which will lead to the accumulation of corporate assets in the form of patents. The methodology is doctrinal, and the paper relies on recent literature on IP and AI, South African law, case law and examples drawn from studies conducted in other countries.
\end{abstract}

\section{Keywords}

Corporate assets; intellectual property; patents; patentability criteria; state of the art; prior art search; artificial intelligence; machine-learning; deep learning; $4^{\text {th }}$ Industrial Revolution. 


\section{Introduction and background}

The importance and impact of intellectual property, known to the subject cognoscenti as IP, cannot be gainsaid. IP permeates almost every aspect of human life. It creates and enables access to high and low culture ${ }^{1}$ but at the same time is responsible for the high price of prescription drugs and the huge profits design companies like Apple make. ${ }^{2}$ It determines whether farmers can plant the seeds they bought in more than one farming season ${ }^{3}$ and whether inventions are the same or different from each other. ${ }^{4}$ In classical literature, IP is indeed an example of an oxymoron. ${ }^{5}$

The creation and protection of IP may be viewed as part of what is loosely referred to as the IP system, a public policy tool aiming to promote aspects of the economy, society, and culture by stimulating creativity and innovation in technology. ${ }^{6}$ Therefore, IP refers to rights given to persons (natural and juristic) over the creations of their minds. Such rights are referred to as IP rights (IPRs), which are timebound exclusive rights under national law. ${ }^{7}$ During the subsistence of the IPR the creator can prevent the use of the product by others in specific ways without prior authorisation. ${ }^{8}$ The creator of an IPR can reap economic benefits from his or her creation directly or indirectly by authorising others. The permission can take the form of licences, which may be voluntary or compulsory. ${ }^{9}$ It is important to emphasise that despite international harmonisation efforts, ${ }^{10}$ IPRs are

Lonias Ndlovu. LLB LLM (Fort Hare) Postgraduate Diploma in Higher Education (UKZN-with distinction) LLD (Unisa). Associate Professor Department of Mercantile Law and Dean, School of Law, University of Venda, South Africa. E-mail: lonias.ndlovu@univen.ac.za. ORCID: https://orcid.org/0000-0003-3993-3783.

Haggart "What is Intellectual Property?" 216.

Haggart "What is Intellectual Property?" 216.

See the Supreme Court of the United States case of Vernon Hugh Bowman $v$ Monsanto Company et al 569 US 278 (2013), in which farmers who bought seeds from Monsanto were permitted to plant the seed in one and only one growing season. Ascendis Animal Health (Pty) Limited v Merck Sharpe Dohme Corporation 20201 SA 327 (CC).

5 An oxymoron is a figure of speech with two contradictory words appearing side by side. In terms of its utility, IP can accommodate good and bad.

Taubman, Wager and Watal Handbook on the WTO TRIPS Agreement 2.

Taubman, Wager and Watal Handbook on the WTO TRIPS Agreement 1.

Taubman, Wager and Watal Handbook on the WTO TRIPS Agreement 1.

The South African Patents Act 57 of 1978 provides for licences generally in ss 53 to 57 while the relevant Agreement on Trade-Related Aspects of Intellectual Property Rights (1994) (TRIPS Agreement) provisions dealing with licences are Arts 21, 28.2, 31, 31 bis, 37.2 and 40.

10 Befitting examples of this are the Patent Cooperation Treaty of 1970, an international patent law treaty, which provides a unified procedure for filing patent applications to protect inventions in each of its contracting states, and the Berne Convention for the 
territorial rights, valid only in the country in which they are registered or acquired. ${ }^{11}$ Natural and juristic persons, including companies, can own IP.

A necessary consequence of a company's legal personality is that it can own property and assets which belong to it. ${ }^{12}$ The different manifestations of IP can be owned by corporate entities as corporate assets forming part of the asset register. Most forms of IP will be created through human endeavour, while advances in technology spurred by the fourth and other industrial revolutions imply that it may be possible to generate IP using machines. This possibility implicates machine learning and artificial intelligence $(\mathrm{AI})$, which may help ensure that the IP generated is original and of high quality. For example, in 2020 the European Patent Office (EPO) declined to grant patent protection to an Al inventor, the "DABUS machine", which was described as "a kind of connectionist artificial intelligence". ${ }^{13}$ The matter was dealt with by the United Kingdom Intellectual Property Office, ${ }^{14}$ the EPO, ${ }^{15}$ and the United States Patent and Trademark Office (USPTO), ${ }^{16}$ with all the different patent offices coming to broadly similar conclusions that the invention could not be registered as a patent because it was created by the Al machine. ${ }^{17}$

Although IP corporate assets may take the form of trade marks, industrial designs, copyright and patents, patents are the most suited for protecting most innovations; hence they are discussed here alongside Al.

This paper discusses the relationship between patents and Al by looking at patentability requirements generally and in South Africa specifically. It aptly illustrates how applying strict patentability criteria may be aided by AI to

Protection of Literary and Artistic Works, an international agreement governing copyright, which was first accepted in Berne, Switzerland in 1886.

11 See generally Zhao 2017 QMJIP 137-155.

12 Cassim "Legal Concept of a Company" 36-38.

13 The issue attracted a lot of academic debate and for a conspectus of views on it, see the following authorities: Flint 2020 Bus L Rev 151-152; Deshpande and Kamath 2020 JIPLP 879-889; and Kidd 2020 Australasian Biotechnology 40-42.

14 The UKIPO decision was issued on 4 December 2019. It is available at UKIPO 2019 https://www.ipo.gov.uk/p-challenge-decision-results/p-challenge-decision-resultsbl?BL_Number=O/741/19.

15 The EPO decision is available at EPO 2020 https://register.epo.org/application?documentld=E4B63OBI2076498\&number=EP1 $8275174 \&$ Ing $=$ en.

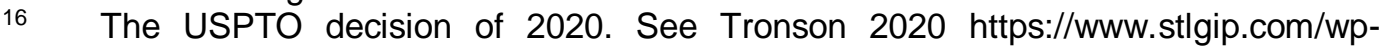
content/uploads/2020/04/USPTO_Al_as_Inventor-r.pdf.

17 For further legal arguments on AI related patentability, see Hattenbach and Snyder 2018 Colombia Science and Technology Law Review 313-318. 
develop inventions capable of beefing up IP corporate assets in the South African legal context.

The paper is divided into two thematic parts. The first part defines and conceptualises patentability criteria and exposes the real possibility of their interfacing with Al. The second part explores possible practical uses of $\mathrm{Al}$ approaches, such as machine learning and deep learning. The Al approaches are linked to the accumulation of corporate assets and the enhancement of patentability criteria. Finally, the paper optimistically concludes on a futurist note that Al will solve most problems associated with the granting of "wrong" patents before sketching a brief research agenda for the future.

\section{Patents, corporate assets, and Al: Definitions, issues, and relationships}

\subsection{A short primer on patents}

Patent law is domestic, and each country has its version of patent laws, which may not necessarily obtain in another country. ${ }^{18}$ Most patent laws, however, protect inventions that are new, inventive, and useful in life.

Patents for products and processes will be granted to inventors or the first persons to file for a patent for 20 years. ${ }^{19}$ Inventions must be new, ${ }^{20}$ must involve an inventive step, ${ }^{21}$ and must be capable of industrial application. ${ }^{22}$ Adequate disclosure of the invention is mandatory so that the invention may be carried out by a person skilled in the art. ${ }^{23}$ The requirement that inventions must be new (novelty) is traceable to $16^{\text {th }}$ century England in Darcy $v$ Allen. ${ }^{24}$ In Darcy $v$ Allen, the granting of patent monopolies was

Hestermeyer Human Rights and the WTO 19.

The commencement of the 20-year period is known in patent law as the priority date. See ss 31 and 33 of the South African Patents Act 57 of 1978 for specifics about priority dates.

Novelty is sometimes synonymous with "non-obvious", as explained in Roman Roller CC v Speedmark Holdings (Pty) Ltd 1995 BP 199 (A) 212-221. Courts generally determine the issue of non-obviousness (see Gentiruco AG v Firestone South Africa (Pty) Ltd 1971 BP 58 (A) 92 and Ensign Bickford v AECl 1998 BIP 271 (SCA) 281CD). Inventions must be non-obvious in terms of the US Patents Act 35 USC $\S 1295$ (2012).

Utility and industrial applicability in South African law requires an invention to be capable of use or application in trade, industry and agriculture (s 25(1) of the Patents Act 57 of 1978).

Per s 25 of the Patents Act 57 of 1978.

Darcy v Allen 72 Eng Rep 830 (1603). Playing cards were the products at stake. 
confined to products that were previously unknown in England. This aimed to curb the danger posed by patent monopolies, which could induce a patentee to demand unreasonably high product prices. ${ }^{25}$ The Statute of Monopolies, ${ }^{26}$ which lasted for 200 years, is still viewed as the first important patent legislation that still informs the patentability criteria to date. ${ }^{27}$

According to South Africa's current Patents Act of 1978, patents will be granted for 20 years from the date of the first application, and prescribed renewal fees have to be paid for the patent to subsist. ${ }^{28}$ South Africa's repealed Patents $A c t^{29}$ of 1952 provided a term of 16 years from the date of lodgement of the complete specification at the Patents Office. ${ }^{30}$ On the ground of inadequate remuneration and/or war loss during the normal term, the 16 years could be extended upon application to the Commissioner of Patents. ${ }^{31}$

A patent application consists of a specification which describes the invention and a section explaining the technology applicable to the invention circumscribing the protected rights claimed - the claims. ${ }^{32}$ The claims define the patentee's rights, and the specification instructs the public about the rest of the details. ${ }^{33}$ The claim or claims, which must relate to a single invention, ${ }^{34}$ must be clear, unambiguous, ${ }^{35}$ and based on what was disclosed in the specification. ${ }^{36}$

$25 \quad$ Darcy $v$ Allen 72 Eng Rep 830 (1603) 831.

26 English Statute of Monopolies, 1623, 21 Jac 1, c 3.

27 According to Mueller Introduction to Patent Law 8, the Venetian Patent Statute of 19 March 1474, passed earlier than the English Statute of Monopolies, 1623, laid the foundation for the first world patent system.

28 The Patents Act 57 of 1978 provides for this in s 46.

$29 \quad$ Patents Act 37 of 1952.

$30 \quad$ Section 28 of the repealed Patents Act 37 of 1952

$31 \quad$ Section 45 of the Patents Act 57 of 1978.

$32 \quad$ Klopper et al Law of Intellectual Property 293.

33 This was affirmed in the cases of Letraset Ltd $v$ Helios Ltd 1972 BP 243 (A); Moroney $v$ West Rand Engineering Works (Pty) Ltd 1970 BP 452 (T)); Selas Corporation of America $v$ The Electric Furnace Company 1982 BP 442 (A); and Deutsche Gesellschaft Fur Schadlingsbekampfung MB v Coopers (South Africa) (Pty) Ltd 1973 BP 447 (CP).

35 For example, in the case of lan Fraser-Johnson v Gl Marketing CC 1993 BP 461 (CP), the use of the word "preferably" to describe the necessity of a cover (an integer) in the second claim was described as an ambiguous surplusage and the claim was disallowed. 
Generally, as national institutions, ${ }^{37}$ patent offices examine compliance with patentability criteria in terms of each country's national laws. ${ }^{38}$ If the requirements are satisfied, patents are granted and published ${ }^{39}$ for information and possible opposition.

Rights in product patents prevent third parties from making, using, offering for sale, selling, or importing the patented product without the patentee's consent. ${ }^{40}$ Similarly, with process patents, third parties with no prior authorisation from the patent holder are prevented from using, offering for sale, selling, or importing the product or products of the patented process. ${ }^{41}$ The enjoyment of patent rights is on a non-discriminatory basis, discounting where the product or process was invented, the technological field, and whether it was locally produced or imported. ${ }^{42}$ The unauthorised use of the invention and the product of the process may attract a claim for damages or an application for an interdict. ${ }^{43}$

It is worthwhile for the patentee to invest in product rather than process patents because market exclusivity for the products is guaranteed for 20 years; other inventors producing the same product through a different process may pose stiff competition for the owner of a process patent. ${ }^{44}$

It is easier to prove the infringement of product rather than process patents because infringing products are easily identifiable, while the same cannot be said of process patents, because the process of obtaining an identical product may be different from that of its patented counterpart. ${ }^{45}$

In some countries the grant of a patent may be contingent on working it locally first. ${ }^{46}$ Because of the local working requirement, the inventor will be compelled to manufacture the product or use the process locally. ${ }^{47}$ The local

Notable regional patent offices that can grant patents which are equivalent to national patents in the member states are the African Regional Industrial Property Organisation (ARIPO), European Patent Office (EPO) and the Organisation Africaine de la Propriete Intellectuelle (OAPI).

Examinations are not provided by all countries. South Africa does not provide for such examinations while the United States, Germany and the EPO do. There is a time within which the application is expected to be published after filing, irrespective of whether a patent has been granted or not.

Hestermeyer Human Rights and the WTO 19.

Hestermeyer Human Rights and the WTO 19.

TRIPS Agreement Art 27.1.

Hestermeyer Human Rights and the WTO 20.

The burden of proof may be reversed, with the defendant being required to prove that he or she is using a different process (see Art 34 of the TRIPS Agreement).

Article 34.1 of the TRIPS Agreement.

See generally Mercurio and Mercurio and Tyagi 2010 Minn J Int'I L 275-326.

On a related note see Reddy 2013 JIPR 15-27. 
working requirement originated from French law. ${ }^{48}$ The law may also disallow the exploitation of certain inventions on the grounds of protecting public order or morality, human, animal, or plant life, health, and the environment. ${ }^{49}$

\subsection{Corporate assets and IP}

A company's assets may be in the form of corporeals (tangibles) ${ }^{50}$ such as land and offices, and incorporeals (intangibles) ${ }^{51}$ such as goodwill and IP. The intangible assets of a company are usually referred to as its intellectual capital. $^{52}$ Almost everything written about intellectual capital may be attributed to Stewart, who wrote a series of articles and published a book on the subject. ${ }^{53}$ How a company manages its intellectual capital depends on the existence and effectiveness of its business strategy. ${ }^{54} \mathrm{~A}$ company's actions and decisions to achieve set business goals considering business competition form the hallmark of its strategy. ${ }^{55}$ Steps required to reach business goals help to guide the process of decision-making. ${ }^{56}$

An effective business strategy ensures that corporate assets, including incorporeal assets such as IP, are managed for the company's benefit. IP is primarily regarded as one of the most critical assets for any business organisation. 57

IP is now regarded as both a business and a legal asset, and its value has steadily increased since the 1970 s. ${ }^{58}$ As a business asset, IPRs have no value by themselves because they become valuable only in the business context, spurred by the expansion of strategic patent management as a business discipline. ${ }^{59}$ IPRs become valuable corporate assets when

The roots are in the French Patents Act of 1791 read together with the Regulation dated 25 May 1791, which, at the pain of revocation, obliged the patentee to work his invention in France within two years of the granting of the patent. Article 27.2 of the TRIPS Agreement.

Van der Walt and Pienaar Introduction to the Law of Property 14-16.

Van der Walt and Pienaar Introduction to the Law of Property 13-14.

52 According to Sullivan 1999 JKM 132, the concept of intellectual capital generally refers to capital that is produced using knowledge and innovation, and companies that are knowledge-intensive achieve their goals through the strategic use of knowledge and innovation.

53 Stewart Intellectual Capital.

54 See generally Lau; Kong and Baark 2012 Journal of Science and Technology Policy in China 49-67.

$55 \quad$ Ireland, Hoskisson and Hitt Understanding Business Strategy 4.

$56 \quad$ Ireland, Hoskisson and Hitt Understanding Business Strategy 5.

$57 \quad$ Ryder and Madhavan Intellectual Property and Business 1.

$58 \quad$ McClure 2015 Chapman L Rev 759.

$59 \quad$ McClure 2015 Chapman L Rev 788. 
reduced to material form and commercialised in the context of each business in line with the business strategy. For example, suppose a pharmaceutical company invents a new drug to treat arthritis and registers a patent. In that case, the patent is a potential asset that is not truly useful to the company unless commercialised and aligned to its business strategy of developing and marketing blockbuster drugs that treat diseases common in elderly patients.

The management of IP as a business asset entails a multidisciplinary approach, including a business strategy, strategic litigation, intellectual asset management, risk management, the licensing of intellectual property, royalty collection and maximisation, franchising, and IP valuation. ${ }^{60}$ Most of the above-mentioned IP management concepts are self-explanatory, but one may note in addition that strategic litigation, risk management, licensing franchising, and royalty maximisation will, in all likelihood, increase the company's asset value and please shareholders.

To view a patent properly as a corporate asset, it is crucial to focus on what the patent does for the business. Patents will increase the value of a company's assets directly through sales of the patented products and indirectly if there are licensing agreements in place. The company can identify the value brought by each patent in its portfolio and attribute the value to a specific business unit in terms of the business strategy. Consequently, some departments or divisions in the company may become more IP intensive than others. In the long run, specific divisions in the company may become responsible for the bulk of the IP outputs. Whether or not a patent constitutes a corporate asset will depend on whether the invention has been commercialised or not.

To gain from IP generally as a corporate asset and specifically from patents, three considerations are essential. Firstly, the company should define its expected gains from IP management and secondly, it should determine how IP will support its business. ${ }^{61}$ Thirdly, the company should choose and follow a defined IP strategy to accomplish the two preceding goals. ${ }^{62}$

$60 \quad$ McClure 2015 Chapman L Rev 759-797.

61 Sullivan and Harrison 2008 WIPO Magazine 1-4.

62 A good example of such an IP strategy would be to incentivise staff working in units that produce more commercialised patents and to channel financial and technological resources to such units to boost the company's asset base through the instrumentality of IP accumulation. 
What companies expect from their IP assets may be motivated by several factors. The motivation may be defensive, ${ }^{63}$ cost-minimising, profitcentered, integrated, collaborative, impromptu, or at an ideal level, visionary. ${ }^{64}$ The defensive mode implies that a company's goal is to maximise its IP assets through accumulation, irrespective of incurring IP administrative costs. The goal is to amass IP for its own sake and to be counted among IP holders and owners. In the cost-minimising context, companies remain defensive but begin to view IP as costly, thus shifting their attention to limiting the costs associated with creating and maintaining their IP assets. The profit-centered approach to IP as a corporate asset kicks in once a company commercialises its IP and licenses it for profit through royalties to support the business. When IP assets are no longer confined to specific departments or units, the approach becomes integrated, and the company may transform into a hub of innovation and invention. At the visionary level, the highest IP management level, companies may use the IP to create more strategic value, considering IP's role in the economy. ${ }^{65}$

Coming to patents, one may ask the rhetorical question: what business roles can patents play as corporate assets? When commercialised, patents can generate profits for companies through the direct sales of patented products and licensing agreements. In this manner companies will derive value from their assets associated with a registered patent. The company may also use patents to strategically position itself as an inventor and innovator, enhancing its image before its peers. To sum up, a company can extract value from its IP generally and from patents, particularly by selling the IP, licensing it to outsiders, using the IP in joint ventures, using it as a market access tool, using the IP to protect its products and services, and creating companies through which the IP is commercialised. ${ }^{66}$

For companies to take full advantage of patents as corporate assets, they should have the infrastructure to spur innovation. Such infrastructure will ensure that only the best inventions get registered as patents.

As highlighted earlier in this paper, for inventions to be patentable, specific patentability criteria must be met. To enforce the patentability criteria, companies should take advantage of the $4^{\text {th }}$ Industrial Revolution and its attendant technological advances, such as Al. In most jurisdictions

\footnotetext{
63 Grimaldi, Grecob and Cricelli 2021 Journal of Business Research 156-164.

64 For a full discussion of these strategies and their implications, see Alexey, Criscuolo and Salter 2009 MIT Sloan Management Review 71-77.

65 Sullivan and Harrison 2008 WIPO Magazine 2.

66 Sullivan and Harrison 2008 WIPO Magazine 2.
} 
patentability criteria are enforced by human beings in patent searches and examinations, leading to some erroneous results. Some of these inaccurate results militate against a company's objective of maximising IP as a corporate asset, because patents may be opposed, revoked or litigated on infringement grounds. Therefore, Al may be used to obtain more accurate results on patentability criteria and enable companies to accumulate durable IP assets whose validity is unlikely to be opposed, revoked, or litigated.

To starkly illustrate how IP may effectively be leveraged as a corporate asset, one needs to look no further than the example drawn from the pharmaceutical industry by Drahos and Braithwaite, ${ }^{67}$ reproduced in the appropriate context by Khotha and Stern. ${ }^{68}$ In the example, typically, when a pharmaceutical company develops a new drug it locates such development within an existing IP strategy that implicates different IP forms. All aspects of the compound, including the dosage methods and manufacture, are protected by patent law, while some vital knowledge is not disclosed and remains protected under trade secrets law. Brand name identity is protected under trademark law, and copyright protects the new drug's mass documentation. This simplistic example shows that strategic planning on a company's part may be interwoven effectively into IP knowledge and an existing pre-planned IP strategy relevant to each company's context.

Before exploring the potential utility of $\mathrm{Al}$ in enhancing patents as corporate assets, it is appropriate to give an expository contextual account of the patentability criteria.

\subsection{Patentability criteria}

Requirements for patentability relate to whether a product or process ${ }^{69}$ is patentable. Simply put, patentability criteria refer to specific attributes/requirements that must be satisfied before a patent can be granted. ${ }^{70}$ Patentability criteria relate to patentable subject matter. ${ }^{71}$ To establish if an endeavor is patentable, one needs to look no further than the TRIPS Agreement ${ }^{72}$ and the South African Patents Act. ${ }^{73}$ An invention is generally patentable if it is new (novel), involves an inventive step, and is

Drahos and Braithwaite Information Feudalism.

Khotha and Stern 2005 SAJIM.

Van der Merwe "Law of Patents" 363.

Tomlinson et al 2019 SAMJ 388.

Oloko 2016 CLB 236-260.

Specifically Art 27 of the TRIPS Agreement.

Generally, s 25 of South Africa's Patents Act 57 of 1978. 
industrially applicable or useful. ${ }^{74}$ It is also possible for a defendant in a patent infringement suit to admit liability but counterclaim for the patent's revocation based on the failure to meet the patentability criteria. In such cases, the onus of proving invalidity rests on the defendant. ${ }^{75}$

An invention is new if it does not form part of the state of the art immediately before its priority date. ${ }^{76}$ The state of the art consists of all matter, whether a product, process, information about either, or anything else which has been made available to the public in South Africa by written or oral description, by use or in any other way. ${ }^{77}$ An invention will not be regarded as new if it is anticipated $;{ }^{78}$ for example, an invention that has taken over all the essential integers of a previous invention is anticipated. ${ }^{79}$ The test to apply in establishing whether an invention has been anticipated is found in Gentiruco AG v Firestone SA (Pty) Ltd, ${ }^{80}$ wherein Trollip JA made it clear that something that has been patented or described in any printed publication is anticipated. ${ }^{81}$ In one case, It was held that an invention whose claims related to purifying water using chlorine, a process well known and documented in scientific literature and other patent specifications, was anticipated and formed part of the state of the art. ${ }^{82}$

Whether an invention involves an inventive step requires a three-legged enquiry. ${ }^{83}$ Firstly a question must be asked about what the state of the art was immediately before the priority date of the invention in question; secondly, whether the invention claimed is a step forward on the state of the art and finally, whether considering the state of the art, the step was inventive (not obvious). ${ }^{84}$ Courts would generally want to establish what the claimed inventive step is, the relevant state of the art on the priority date,

74 Section 25(1) of the Patents Act 57 of 1978. South African law specifically requires that the invention must be useful in trade, industry and agriculture.

This was established in the following cases: Gentiruco AG v Firestone SA (Pty) Ltd 19721 SA 589 (A) 629E-F; Roman Roller CC v Speedmark Holdings (Pty) Ltd 1996 1 SA 405 (A) 412F-G; Coflexip SA v Schlumberger Logelco Incorporated 2001 BIP 1 (CP) $9 \mathrm{H}-10 \mathrm{~A}$. Roman Roller CC v Speedmark Holdings (Pty) Ltd 1995 BP 199 (A).

Section 25(6) of the Patents Act 57 of 1978.

Netlon v Pacnet 19773 SA 840 (A) $861 \mathrm{H}-862$.

Buckman Laboratories (Pty) Ltd v Bromine Compounds Ltd 2008 ZASCA 37 (28 March 2008).

80 Gentiruco AG v Firestone SA (Pty) Ltd 19721 SA 589 (A).

81 The learned Judge based his opinion on the Patents Act 9 of 1916, which was the current law then. Buckman Laboratories (Pty) Ltd v Bromine Compounds Ltd 2008 ZASCA 37 (28 March 2008) para 18. (A). 
how the step goes beyond the state of the art, and whether taking the step is not obvious to a person skilled in the art. ${ }^{85}$

A practical example could be invention $A$, a bitter square pill, black and not aesthetically appealing, to cure mild headaches. Invention $B$, a claimed improvement on $A$, is now yellow in colour, round and sweet, but having the same chemical composition and curing the same disease with the same efficacy. Having regard to the state of the art before invention $B$, the invention is obvious to someone skilled in the art and does not involve an inventive step. The only additions were the shape, the colour, and sweetness; hence these cannot be regarded as significant components of inventiveness.

The TRIPS Agreement is not directly prescriptive of how each World Trade Organization (WTO) Member ought to define what constitutes patentable subject matter and what may be excluded from patentability. However, there are prohibitions against discrimination based on fields of technology. ${ }^{86}$ Although the TRIPS Agreement does not allow Members to discriminate against a field of technology, differentiation between fields of technology does occur in practice. Each field of technology is unique, and differentiation may be necessitated by practical considerations such as standards for examining patents. ${ }^{87}$ For example, in pharmaceutical patents India does not recognise patents for naturally occurring substances, new forms of known substances in which enhanced therapeutic efficacy is not shown, new uses of known substances, mere admixtures (combinations), and treatment methods. ${ }^{88}$ Meanwhile, in Argentina since 2012 pharmaceutical patents on any new form of known substances will not be allowed, regardless of increased efficacy. ${ }^{89}$

Novelty, inventiveness, and industrial applicability are not defined in the TRIPS Agreement; hence each member state may define the terms in any

85 Ensign Bickford $v$ AECI 19991 SA 70 SCA. See also the earlier related case of Roman Roller CC v Speedmark Holdings (Pty) Ltd 19961 SA 405 (A) 413.

86 TRIPS Agreement Art 27.1.

87 Baker 2019 https://www.bu.edu/gdp/files/2020/05/ARIPO-Member-Statesobligations-and-flexibilities-under-the-WTO-TRIPS-Agreement-March-2019.pdf. Section 3(d) of India's Patents Act 39 of 1970 as amended. For the legal historical developments and a clear articulation of India's negotiation stance on the issue at the WTO, see Watal "Patents" 295-320. Industry, Ministry of Health and National Institute for Industrial Property) published in the Official Bulletin on 8 May 2012. 
manner it deems fit for its national context. ${ }^{90}$ The autonomy alluded to above may then be used to inform strict patentability criteria that may be embedded in Al prior-art-search algorithms, which are discussed in detail in paragraph three and four below.

Before inventors can experiment with ideas or processes to develop new products, they must search the available patent information database. ${ }^{91}$ The patent information assists inventors in conceiving, screening, and developing ideas into patentable final products. ${ }^{92}$

Searching the thicket of patent information is not an easy task, and human endeavours alone will not guarantee the quality of such information. Other technology-based approaches, such as Al, will help make the search process yield more accurate results.

The main challenge relating to patentable subject matter in South Africa is that despite the prescriptive provision in section 25, patents are not examined in South Africa to ascertain whether the patentability criteria are met but to ascertain compliance with formalities. ${ }^{93}$ To achieve legal certainty, recourse must be had to case law. Therefore, an effective Al strategy entails reading the case law closely, alongside the science applicable to the field of technology. This calls for a multidisciplinary approach in creating the relevant and effective prior-art-search algorithm. Al is part of the $4^{\text {th }}$ Industrial Revolution; hence, brief remarks are necessary for full contextualisation.

\section{Brief remarks on the $4^{\text {th }}$ Industrial Revolution and Al}

The $4^{\text {th }}$ Industrial Revolution is also called Industry 4.0,94 and many associate it with technological innovation. However, it also entails "an assemblage of novel technologies and forms of application, with discrete degrees of technical maturity and systemic effects". .55 There have been

\footnotetext{
90 This has a textual basis in Art 1.1 of the TRIPS Agreement, which provides that "Members may, but shall not be obliged to, implement in their law more extensive protection than is required by this Agreement". Kalanje 2017 https://iettn.ieee-ies.org/role-intellectual-property-innovation-newproduct-development/. Kalanje 2017 https://iettn.ieee-ies.org/role-intellectual-property-innovation-newproduct-development/.

$93 \quad$ Ndlovu 2015 PELJ 799.

94 Franka; Dalenogare and Ayala 2019 International Journal of Production Economics 15-26.

95 Ocen et al 2020 Journal of Engineering 2.
} 
three other industrial revolutions, each one having its distinct features and hallmarks. ${ }^{96}$

The Industrial Revolution in England between 1760 and 1840 is now largely referred to as the First Industrial Revolution. ${ }^{97}$ During the First Industrial Revolution machines began to replace human labour and automation became fashionable. ${ }^{98}$ The First Industrial Revolution is also known as "the age of manufacture". 99

The Second Industrial Revolution was born of the first, and its main hallmark is electromagnetism, a science responsible for the generation of up to $90 \%$ of our electricity even today. ${ }^{100}$

The Third Industrial Revolution happened in the USA in 1960. It introduced semiconductor technology, which is essential in computers and smartphones and is famed for automating communication using ones and zeros. ${ }^{101}$ It is responsible mainly for the automation of industrial production through electronics and information technology. ${ }^{102}$

The term Fourth Industrial Revolution (41R) was coined by the founder and executive chairman of the World Economic Forum, Klaus Schwab, in his renowned book. ${ }^{103}$ The $4 \mathrm{IR}^{104}$ is described as a confluence of all the technologies around cyber, physical, and biological technologies, more specifically in that:

The 4th Industrial Revolution is an era where people are using smart, connected and converged Cyber, Physical and Biological systems and smart business models to define and reshape the social, economic and political spheres. ${ }^{105}$

Marwala 2019 https://youtu.be/Ss68_JZlwL8.

See generally, Barham From Hand to Handle.

Church 1996 Historical Journal 535-543.

Church 1996 Historical Journal 535.

100 For an account of the technological differences between the two revolutions, see Agarwal and Agarwal 2017 Saudi J Humanities Soc Sci 1063-1065.

101 Xu, David and Kim 2018 International Journal of Financial Research 90.

102 Xu, David and Kim 2018 International Journal of Financial Research 90.

103 Schwab Fourth Industrial Revolution.

104 De Koker and Du Plessis 2020 SAJIM aptly observe that the fourth industrial revolution is now called the 4IR.

105 Paragraph 6.1 of the Report of the Presidential Commission on the 4th Industrial Revolution (Department of Communications and Digital Technologies 2020 https://www.gov.za/sites/default/files/gcis_document/202010/43834gen591.pdf 47). 
The 4IR is associated with the emergence of many specific technologies, most of which will lay the foundation or superstructure for further specialised applications. ${ }^{106}$

At the heart of the 4IR are biotechnology, Al, cloud computing, blockchain technology, the Internet of things, quantum computing, 3D printing, additive manufacturing, robotics, and the production of new materials. ${ }^{107}$ Biotechnology is important in the IP context when one looks at, for example, pharmaceutical patents and the industrial manufacture and production of medicines. An important industrial application of biotechnology is in the manufacture of biological medicines and related products using genetically modified animals, plants, cells, fungi, and yeast. ${ }^{108}$ The internet of things is responsible for the invisible embeddedment of the information and communication systems around us, thus enabling device-to-device and human-to-device interactions. ${ }^{109}$ Blockchain technology, among other things, allows the safe and secure transfer of encrypted data and information between devices and generally ensures safe communication. ${ }^{110}$ Quantum computing facilitates the creation of super-fast computers, while cloud computing allows the provision of computing power as a service. ${ }^{111}$ These technologies are useful practically and will make manufacturing, the production of goods and the provision of services fast and efficient. Companies employing such technologies will, of course, manage the IP spinoffs thereof.

To summarise the opportunities likely to be brought by the $4 \mathrm{IR}$ in the context of government and business, one can reiterate the apt observation by $\mathrm{Xu}$, David, and Kim that the 4IR will bridge the gap between inventors and markets, facilitate an active role for $\mathrm{Al}$, integrate different techniques and domains, and improve lives through techniques such as robotics and improve interconnectedness. ${ }^{112}$

Because this paper deals with using Al to enhance patents' value as IP assets, it is essential to define $\mathrm{Al}$ and its associated terminology.

\footnotetext{
106 Giaglis 2018 Cyprus Review 157-158.

107 See for instance Ramadoss, Alam and Seeram 2018 IJES 55-63.

108 Sengupta Biological Drugs 1-11.

109 Ramadoss, Alam and Seeram 2018 IJES 56.

110 Ramadoss, Alam and Seeram 2018 IJES 58.

111 Singh and Sachdev 2014 ICROIT 397-400.

112 Xu, David and Kim 2018 International Journal of Financial Research 91.
} 


\subsection{Al and important associated terms}

Although a precise definition of $\mathrm{Al}$ is difficult to pin down, Al generally refers to the technology that allows humans to build intelligent machines. ${ }^{113}$ Such machines will then exhibit aspects of human intelligence. ${ }^{114} \mathrm{Al}$ has been defined as "the science of making machines do things that would require intelligence if done by men". ${ }^{115}$ Another author, John McCarthy, defined Al as "the science and engineering of making intelligent machines". ${ }^{116}$ I found the definition below, extracted from a 2016 Stanford University report on Al in 2030 , to be very informative:

Artificial intelligence is that activity devoted to making machines intelligent, and intelligence is that quality that enables an entity to function appropriately and with foresight in its environment. ${ }^{117}$

It becomes clear from the definitions that $\mathrm{Al}$ has been around for quite a while, albeit in different guises. For example, the scientific calculator (a machine) performs activities that the human brain can perform but performs mathematical functions faster than humans. Therefore, by making intelligent machines, tasks that traditionally have been performed by humans can now be performed by machines, which do not have human fallibilities. Good examples of human fallibilities are getting tired, making mistakes, getting emotional, being absent-minded, and paying less attention to detail.

The reliance on intelligent machines is likely to guarantee more production and efficiency. In the context of this paper the production of more IP products will boost companies' asset registers. However, one must not ignore the fact that intelligent machines do age through wear and tear, and are only as good as the information fed into them by human beings.

Machine learning, which has been described as a statistical approach to making machines intelligent, is an important offshoot of $\mathrm{Al}$ in the context of this paper. Natural language processing, deep learning, computational intelligence and cloud computing are other $\mathrm{Al}$ technologies relevant to patent searches and patentability criteria. Most Al uses computer programmes (algorithms) ${ }^{118}$ to learn. For example, deep learning and

113 Gennatas, Chen and Giger Artificial Intelligence Medicine.

114 Bock, Wolter and Ferrell 2020 Journal of Services Marketing 317.

115 Andersen et al $2018 \mathrm{https}: / /$ www.accessnow.org/cms/assets/uploads/2018/11/Aland-Human-Rights.pdf 8.

116 Andersen et al $2018 \mathrm{https}: /$ www.accessnow.org/cms/assets/uploads/2018/11/Aland-Human-Rights.pdf 8.

117 Stanford University 2016 https://ai100.stanford.edu/sites/g/files/sbiybj9861/f/ai100 report10032016fnl_singles.pdf.

118 Panch, Szolovits and Atun 2018 Journal of Global Health 2. 
natural language processing (forms of machine learning) are based on data and statistics. ${ }^{119}$ Such data can, in the context of this paper, be patentrelated data. With the advent of big data, which uses Al technologies to analyse vast amounts of data, the management of bulky and complicated patent information will become easier. This can be made possible by designing an algorithm that can analyse complex data, make predictions and read with more accuracy.

As shown in the analysis immediately below, Al technologies have a lot of potential to ensure that companies boost their corporate assets and appropriately apply patentability criteria. Using Al, machine learning, and deep learning, patent data can be analysed accurately and adequately to isolate the state of the art so that companies can extract business value from IP. Self-learning algorithms can be used as tools for effective IP management with positive results for companies.

The relationship between $\mathrm{Al}$ and law, on the one hand, and Al and IP on the other is now the subject of a substantial body of literature. The seminal texts include the 2018 Research Handbook on the Law of Artificial Intelligence, edited by Barfield and Pagallo. ${ }^{120}$ The handbook organises law and AI themes into five parts dealing with law and $\mathrm{Al}$ generally; the regulation of $\mathrm{Al}$; $\mathrm{Al}$, fundamental rights and constitutional law; $\mathrm{Al}$ and IP, including $\mathrm{Al}$ and its interface with patents and copyright; and Al applications. A detailed analysis of the scope of Al under all the listed themes is beyond the scope of this paper, which focusses on the possible use of $\mathrm{Al}$ to aid patent searches and examinations in South Africa for companies to have good quality patents as corporate assets.

\section{Discussion and analysis: The interface between patents as corporate assets, Al, and patentability criteria}

The central argument this paper has advanced thus far is that Al can be used in patent searches and examinations with accurate results, leading to higher quality patents. Such high-quality patents will form part of a corporate entity's assets. Because such patents are unlikely to infringe on other existing patents, they are assets worth investing in and keeping for the long term. Viewed in this way, Al can assist corporates in accumulating patents as corporate assets. The discussion following immediately below elaborates on this initial premise.

\footnotetext{
119 Panch, Szolovits and Atun 2018 Journal of Global Health 2.

120 Barfield and Pargallo Research Handbook on the Law of Artificial Intelligence.
} 


\subsection{IP and corporate assets}

The point that IP is a corporate asset cannot be overemphasised. IP becomes a corporate asset of value when it becomes commercialised and can generate income for the company owning it. Commercialisation "constitutes immediate, measurable market acceptance for outputs"121 such as patents. Many scholars view commercialisation as a process through which innovation is introduced into the market. ${ }^{122}$ Razak, Murray, and Roberts, cited by de Koker and Du Plessis, ${ }^{123}$ express the opinion that "commercialisation success is about converting ideas and new innovations into new marketable products". ${ }^{124}$ The components of a commercialisation life cycle, namely "idea generation, research, concept development and testing, analysis, product or service development, market testing, and marketing and commercialization", ${ }^{25}$ apply mutatis mutandis when viewing IP as a corporate asset. Before IP or a patent can become a corporate asset, it starts as an idea which a company embraces, which leads to the company investing in related research, further development, testing analysis, patenting, marketing, and commercialisation (at which stage the IP becomes an exact IP asset with value).

The value of an asset depends on the business worthiness attributed to it. ${ }^{126}$ Through exclusivity, IP allows companies to build their competitive and business value. ${ }^{127}$ To maximise the business value of IP, companies must embrace a well-established IP culture, which through an enabling IP policy incentivises IP generation, values IP, evaluates risk management strategies, licenses the IP, markets it, and takes IP dispute resolution seriously. ${ }^{128}$ Different forms of IP have different business value depending on the type of industry. ${ }^{129}$ For example, a technology company will value patents more than it does copyright, which may be of great importance to a publishing company.

For companies to invest profitably in IP, innovation, and related products, it should not be easy to patent anything by copying, and the state of the art should be easily accessible to all prospective investors and patent offices.

\footnotetext{
121 Perkmann, Tartari and Mckelvey 2013 Research Policy 423.

122 See for example, Peredy and Laki 2020 IJEMS 56-74; and Wang, Phillips and Yang 2020 Journal of Business Research 255-266.

De Koker and Du Plessis 2020 SAJIM 2.

Razak, Murray and Roberts 2014 Knowledge and Process Management 260-269.

De Koker and Du Plessis 2020 SAJIM 2.

Kankanala 2012 JIPR 369-373.

Kankanala 2012 JIPR 369.

Kankanala 2012 JIPR 370-373.

Kankanala 2012 JIPR 369.
} 
For those companies that can afford it, an investment in machine learning technologies capable of detecting state of the art information accurately is worthwhile. For others, dependence on the state remains the only viable option through the Companies and Intellectual Property Commission. It is also possible for state departments to invest in Al technology to weed out undeserving patents, and this is encouraged. Patents that are not part of the state of the art are likely to complete the statutory 20-year term and weather the patent examination, opposition, and revocation storms. It is almost an axiom that where strong patents exist, companies that own them will have their IP assets guaranteed and boosted.

An Al prior art search would render a patent a better corporate asset than is currently the case in South Africa for reasons lying outside current South African law. Although there is no evidence of Al enhancing the value of patents in South Africa, such evidence does exist in studies carried out elsewhere. ${ }^{130}$

\subsection{Al and patentability criteria}

Currently in South Africa one can do a physical and Boolean online prior art search. For a physical patent search an application is made to the Registrar of Patents, and upon payment of a prescribed fee requested documents may be furnished to the applicant. This type of search is laborious, cumbersome and not very accurate as some prior art may be missed in the thicket of patent documents in the Patents Office. The online Boolean search may be viewed as the better alternative, but it also has its significant shortcomings in the South African context. For example, most patents searched online have only summaries attached to them, ${ }^{131}$ and it will not be easy for applicants to compare the prior art without access to the specification and the claims.

A typical application for a patent in South Africa commences with the applicant submitting the application forms for either a provisional or a complete patent to the patents office upon paying the prescribed fee. ${ }^{132}$ The Patents Office examines the application on formalities only and does not

\footnotetext{
130 See, for instance, an illustration by Genin and Zolkin 2021 World Patent Information 1-4 relating to the enhancement of patent assets quality using Al methods, artificial neural networks and machine learning in similarity searches in Russia.

131 Johnson and Johnson 1957 https://iponline.cipc.co.za/iponlineTemp/ patents/65293_20210201185914NI.pdf.

132 In South African law a specification can either be provisional or complete as contemplated by s 32 of the Patents Act 57 of 1978.
} 
look at the substance. ${ }^{133}$ Suppose the formal requirements, such as filling in the correct documents using the correct forms and paying the prescribed fee, are satisfied. In that case the application is accepted, published in the Patent Journal, and a patent granted to the applicant ${ }^{134}$ for 20 years. ${ }^{135}$ Although a prior search is advisable, it is not mandatory, and patent examination is not contemplated; hence many underserving patents are granted in South Africa. ${ }^{136}$ The South African online patent search facility provides for a simple and advanced search. A simple search can be done based on the application number, patent title, or the inventor's name. ${ }^{137} \mathrm{An}$ advanced search expands the list of possible search items in addition to those applicable in a simple search. ${ }^{138}$ However and very peculiarly, in both types of search no provision is made for tying in keywords associated with the state of the art.

In contradiction, in the United States of America, when an applicant files an application with the USPTO, the office assigns the application an examiner who is specialised in the field of technology to which the application belongs. ${ }^{139}$ To determine whether the application is new, involves an inventive step, and is useful to a person in the relevant field, the examiner searches the database for previously issued patents, publications, patent applications, and other related inventions. ${ }^{140}$ Members of the public, researchers, and inventors can search the USPTO electronic database and access both the full text and the image databases. ${ }^{141}$ It is possible to conduct three types of online patent searches: a quick search, an advanced

133 Although s 34 of the Patents Act 57 of 1978 provides that the "registrar shall examine in the prescribed manner every application for a patent and every complete specification accompanying such application", in practice this does not happen. This is the so-called depository system, which results in the granting of weak and undeserving patents. According to the publication by Fix the Patent Laws Patent Barriers to Medicine Access 11, patents granted under this system do not meet the country's patentability criteria.

Section 46 of the Patents Act 57 of 1978 provides that the duration of a patent shall be 20 years from the date of application, subject to the payment of renewal fees by the patentee.

The search can be conducted on the Companies and Intellectual Property Commission (CIPC) online search portal (CIPC 2021 https://iponline.cipc.co.za/).

137 CIPC 2021 https://iponline.cipc.co.za/.

138 This search type may be based on any or all the following: application number, title of invention, application date, grant date, reference number, patent type, PCT patent status, IPC classification, PCT number, address for service name, applicant/patentee, inventor name.

139 Carrier 2011 UC Davis L Rev 103-135.

140 Carrier 2011 UC Davis L Rev 106. On a related note see Doran and Webster 2019 World Patent Information 39.

141 USPTO $2021 \mathrm{https}: / / w w w . u s p t o . g o v /$ patents/search. The full text database has patent records dating back to 1976 and PDF images of all patents dating back to 1790. 
search, and a patent number search. The advanced search is the most comprehensive. Through it one can access complete information about the patent, including the title, abstract, cross-references to existing patents, claims, description, summary, descriptions of drawings and detailed descriptions. ${ }^{142}$

The US system, which employs patent examinations and mandates patent searches, has an easily navigable online search system. However, the system is not foolproof and does require further improvement and refinement, considering the $\mathrm{Al}$ opportunities presented by the 4IR. Although South Africa recently recruited and trained patent examiners, ${ }^{143}$ they are yet to start examining patents and, in the meantime, assist in patent searches. ${ }^{144}$ The weaknesses in the patent systems of the two jurisdictions compared above may be remedied using Al.

How then can $\mathrm{Al}$ aid patent searches and examinations?

\subsubsection{Al and patent searches and examinations}

Many patent lawyers spend a lot of time analysing patent claims and placing them before patent authorities. ${ }^{145}$ The better part of the claim analysis is spent on scrutinising novelty, inventiveness, and the possible utility of products or processes encapsulated in a patent. ${ }^{146}$ The law could benefit from Al due to the time and resources saved by the use of automated processes of establishing the applicability of the patentability criteria.

The possibilities of using $\mathrm{Al}$ in patent searches and examinations are vast, and tapping into this technology for the benefit of patentability and the accumulation of IP assets by corporates is not a remote possibility. The actual and potential use of Al may also be gleaned from other legal fields,

142 See one result yielded by my search for COVID-19 possible treatments at USPTO 2021 http://patft.uspto.gov/netacgi/nph-Parser?Sect1=PTO2\&Sect2=HITOFF\& $\mathrm{u}=\% 2 \mathrm{Fnetahtml \% 2FPTO} \% 2 \mathrm{Fsearch}-\mathrm{adv} \cdot \mathrm{htm} \& \mathrm{r}=5 \& \mathrm{p}=1 \& \mathrm{f}=\mathrm{G} \& \mathrm{l}=50 \mathrm{~d} \mathrm{~d}=\mathrm{PTXT} \& \mathrm{~S} 1=$ (covid-19+AND+vaccine)\&OS=covid-19+and+vaccine \&RS=(covid-19+AND+ vaccine), which unearthed the patent titled Methods and Compositions for Treating Conditions Associated with an Abnormal Inflammatory Response, US Patent number 10292951.

143 On 7 August 2018 on its Facebook page, the CIPC reported that its patent examiners were being trained by WIPO, the EPO and the South African Institute of Intellectual Property. See CIPC 2018 https://www.facebook.com/theCIPC/posts/patentexaminers-are-properly-and-regularly-trained-by-world-intellectualproper/2173025269582643/.

144 CIPC Second Quarter Performance Report 18-19.

145 Chikhaoui and Mehar $2020 \mathrm{JLERI} 1$.

146 Chikhaoui and Mehar $2020 \mathrm{JLERI} 1$. 
such as health and human rights, ${ }^{147}$ and closer to home, copyright. ${ }^{148}$ For example, using algorithms machines can compare prior art more accurately than humans $\operatorname{can}^{149}$ and ensure that only deserving patents are filed and registered.

The Internet of things allows for valuable data to be retrieved and collected for use in predicting future scenarios, such as the likelihood of patent growth in specific fields of technology. Because everything will be connected through the Internet of things, ${ }^{150}$ it will be easier to retrieve the most important information about patent specifications, especially the claims that define the essential integers of an invention.

Machine learning, natural language processing, and deep learning have led to the automation of tasks traditionally the preserve of humans. ${ }^{151}$ Some deep learning models use knowledge graphs that, in addition to technical features, also contain those technical features' essential relationships. Additionally, it has been reported that deep and machine learning may be used to establish novelty, the existence of an inventive step, and the utility of an invention. ${ }^{152}$ Therefore, machine and deep learning Al approaches may help patent searching, going beyond the traditional South African online Boolean search.

Machine learning algorithms ${ }^{153}$ can detect patterns in data, learn these over time through repetition, automate complex tasks and make predictions. ${ }^{154}$ This may be adapted to patent searches with such retrieved patent data enabling the prospective inventor to sift through relevant and irrelevant data (search results). Machines can detect data patterns, which may help quantitative legal prediction, ${ }^{155}$ the main component in patent searches and examinations.

Talking about patentability criteria and patent searches, one cannot avoid discussing patent analytics, which permeates most discussions informing

\footnotetext{
147 See, for example, Andersen et al 2018 https://www.accessnow.org/ cms/assets/uploads/2018/11/Al-and-Human-Rights.pdf.

148 Mathur 2020 JIPR 5-14.

149 Hattenbach and Glucoft 2015 STLR 42.

150 De Koker and Du Plessis 2020 SAJIM 4.

151 Gravett 2020 PELJ 2.

152 Chung and Sohn 2020 Technol Forecast Soc Change 1-9.

153 According to Balsmeier; Assaf and Chesebro 2017 JEMS 536, patent data covers disparate fields of technology and machine learning will help in the disambiguation of the data.

154 Surden 2014 Wash L Rev 89.

155 Surden 2014 Wash L Rev 88.
} 
my analysis above. The science behind the analysis of large amounts of patent information, comparing it to existing data to expose relationships and patterns, constitutes patent analytics. ${ }^{156}$ Patent data are the largest repository of technical information, ${ }^{157}$ and the latest technology and the state of the art are found in this repository. Patent analytics becomes very relevant and valuable to $\mathrm{Al}$ when used in conjunction with machine learning and deep learning ${ }^{158}$ to analyse patent data. Intellectual property analytics in a business context has three stages: pre-processing, processing, and post-processing. ${ }^{159}$ The pre-processing stage involves collecting data, extracting information, and preparing it to check its quality, correctness, and completeness. ${ }^{160}$ The information is analysed using various methods to aggregate, identify, and cluster it for meaning at the processing stage. ${ }^{161}$ The post-processing stage is also known as covered knowledge and leads to evaluating the results from the processing stage to support decisionmaking strategically. ${ }^{162}$ Therefore, the application of Al methods, namely machine learning, deep learning, and artificial neural networks to intellectual property analytics will enable examiners and prospective inventors to access accurate information relating to the state of the art and thus to comply with the patentability criteria. South Africa is urged to consider taking advantage of this technology.

On a related note, in as early as 2016 the editorial of the World Patent Information published an article in which the Australian Patents and Trade Mark Office, IP Australia, and the USPTO was said to have shown signs of embracing $\mathrm{Al}$ technologies to assist the advancement of IP, albeit in a slightly different manner in two examples. ${ }^{163}$ The first example was the reference to IP Australia's launch of Alex, a virtual assistant who assists online visitors with trade mark queries. In March 2015, during a Patent Quality Summit, the USPTO announced that it would be launching a more advanced automatic search tool to replace the Patent Linguistic Utility Service, which uses an algorithm that identifies and analyses frequently used words to retrieve US patent data. ${ }^{164}$ The new US tool is expected to

\footnotetext{
156 For a detailed literature review on IP analytics, see Aristodemou and Tieztze 2018 World Patent Information 37.

Aristodemou and Tieztze 2018 World Patent Information 38. Aristodemou and Tieztze 2018 World Patent Information 39. Aristodemou and Tieztze 2018 World Patent Information 40. Aristodemou and Tieztze 2018 World Patent Information 40. Aristodemou and Tieztze 2018 World Patent Information 41. Aristodemou and Tieztze 2018 World Patent Information 42. Editorial 2016 World Patent Information A1-A3.

Editorial 2016 World Patent Information A1-A2.
} 
improve "keyword stemming, concept-semantic, and relational word searching capabilities". 165

The South African patent system has been caustically criticised on several grounds, including that it is depository, encourages evergreening, and does not accommodate patent searches, examinations, and pre-grant opposition. ${ }^{166}$ Most if not all of the problems identified emanate from the fact that patentability criteria are not strictly enforced in South Africa for several reasons, including financial or administrative ones.

Embracing $\mathrm{Al}$ and its associated technologies will eliminate most of the problems identified here. It may be time for the Presidential Commission on the Fourth Industrial Revolution to come to the party and conceive a project that will help the CIPC integrate AI into its systems, especially patent searches and examinations. ${ }^{167}$

While it may not be apparent to a skeptical reader how the arguments and descriptions above demonstrate how Al would make patents better assets, the following must be emphasised in closing this analysis section.

Although Al-generated prior art searches may yield more accurate results, ${ }^{168}$ such searches are not expressly mentioned in the current South African Patents Act. While the statutory position remains unclear, the current legal regime, over and above the other weaknesses discussed above, may be characterised as woefully inadequate to deal with the recent growth in the use of Al systems. The prevailing legal position is that "only human and technology-assisted intellectual output is protected by IP law"; 169 hence Al-assisted patent searches will be permitted in South Africa. Because Al-assisted prior art searches are more accurate than other searches, the resultant patents will not form part of the state of the art, and companies owning such patents will have valuable corporate assets, in

\footnotetext{
165 Editorial 2016 World Patent Information A2.

166 See generally Ndlovu 2014 Speculum Juris 70-100. See further DTI 2018 https://www.gov.za/sites/default/files/gcis_document/201808/ippolicy2018phasei.pdf 14-27.

167 In the Report of the Presidential Commission on the 4th Industrial Revolution, the phrase "intellectual property" is mentioned nine times, and in those nine instances where IP is referred to, there is no express reference to leveraging Al technologies to aid the current flawed patent system (Department of Communications and Digital Technologies 2020 https://www.gov.za/sites/default/files/gcis_document/ 202010/43834gen591.pdf).

168 Davies 2011 CLSR 601.

169 Ncube Science, Technology \& Innovation and Intellectual Property 8.
} 
addition to other assets they own. Therefore, Al will play a significant role in enhancing the value of patents as corporate assets.

\section{Valedictory remarks and possible areas for further research}

In this paper, I have demonstrated the relationships and linkages between $\mathrm{IP}$, patents, corporate assets and $\mathrm{Al}$ to show that companies and patent offices can enhance patents' quality by resorting to Al. The use of $\mathrm{Al}$, specifically data analytics generally and IP analytics, will ensure that accurate prior art search results containing few or no errors are obtained faster through the instrumentality of machines before further scrutiny and analysis by human subjects. The paper has reviewed the legal and other literature on AI and IP and contextualised it in the South African context. There has been an increased interest in the relationship between patents and $\mathrm{Al}$, considering increasing instances of patent evergreening and the use of previously granted patents to block new patents and stifle innovation. ${ }^{170}$ Al, specifically the use of machine learning and data analytics, is presented in this paper as the panacea. The paper has also partially confirmed the potential utility of $\mathrm{Al}$ in enhancing patent quality in the South African context. If patent quality improves, companies will expand their IP assets and extract value from IP generally and patents in particular, especially as corporate assets.

Further research is required to identify and recommend specific Al technologies in other IP fields such as plant variety protection, trade secrets, copyright, trade marks, and industrial designs. Al remains unchartered territory for IP scholars in many parts of the world. For example, legal practice requires high cognitive abilities, ${ }^{171}$ and Al algorithms cannot replicate humans' most advanced intellectual skills, such as analogical reasoning. With time and further research, the situation may change and will surely change.

As a futurist technology Al does have its blemishes. Some authors have described these blemishes as challenges. ${ }^{172}$ From the perspective of a developed and developing country, there is a reasonable apprehension of creating technology monopolies, which may exacerbate social inequalities.

170 See Hill 2014 Expert Opinion on Therapeutic Patents 839-843, tackling evergreening from the perspective of pharmaceutical patents.

171 Surden 2014 Wash L Rev 87.

172 See for example Xu, David and Kim 2018 International Journal of Financial Research 92-94. 
This may further manifest itself in unequal countries such as South Africa, where the divide between rich and poor is vast and keeps widening.

There is a real need to initiate a multidisciplinary study that will explore novel ways of using Al to improve and enhance the IP landscape in South Africa.

\section{Bibliography}

\section{Literature}

Agarwal and Agarwal 2017 Saudi J Humanities Soc Sci

Agarwal $\mathrm{H}$ and Agarwal R "First Industrial Revolution and Second Industrial Revolution: Technological Differences and the Differences in Banking and Financing of the Firms" 2017 Saudi J Humanities Soc Sci 1062-1066

Alexey, Criscuolo and Salter 2009 MIT Sloan Management Review Alexey O, Criscuolo P and Salter A "Does IP Strategy have to Cripple Open Innovation?" 2009 MIT Sloan Management Review 71-77

Aristodemou and Tieztze 2018 World Patent Information

Aristodemou $L$ and Tieztze $F$ "The State-of-the-Art on Intellectual Property Analytics (IPA): A Literature Review on Artificial intelligence, Machine Learning and Deep Learning Methods for Analyzing Intellectual Property (IP) Data" 2018 World Patent Information 37-51

Balsmeier, Assaf and Chesebro 2017 JEMS

Balsmeier B; Assaf $\mathrm{M}$ and Chesebro $\mathrm{T}$ "Machine Learning and Natural Language Processing on the Patent Corpus: Data, Tools and New Measures" 2017 JEMS 535-553

Barfield and Pargallo Research Handbook on the Law of Artificial Intelligence

Barfield W and Pargallo U (eds) Research Handbook on the Law of Artificial Intelligence (Edward Elgar Cheltenham 2018)

Barham From Hand to Handle

Barham L From Hand to Handle: The First Industrial Revolution (Oxford University Press London 2013)

Bock, Wolter and Ferrell 2020 Journal of Services Marketing Bock DE, Wolter JS and Ferrell OC "Artificial Intelligence: Disrupting what We Know about Services" 2020 Journal of Services Marketing 317-334 
Burrell Burrell's South African Patents and Design Law

Burrell TD Burrell's South African Patents and Design Law $3^{\text {rd }}$ ed (LexisNexis Butterworths Durban 1999)

Carrier 2011 UC Davis L Rev

Carrier MA "Post-Grant Opposition: A Proposal and a Comparison to the America Invents Act" 2011 University of California, Davis 103-135

Cassim "Legal Concept of a Company"

Cassim R "The Legal Concept of a Company" in Farouk HI Cassim (ed) Contemporary Company Law $2^{\text {nd }}$ ed (Juta Cape Town 2012) ch 2

Chikhaoui and Mehar $2020 \mathrm{JLERI}$

Chikhaoui E and Mehar S "Artificial Intelligence (AI) Collides with Patent Law" 2020 JLERI 1-10

Chung and Sohn 2020 Technol Forecast Soc Change

Chung $\mathrm{P}$ and Sohn S "Early Detection of Valuable Patents Using a Deep Learning Model: Case of Semiconductor Industry" 2020 Technol Forecast Soc Change 1-9

Church 1996 Historical Journal

Church R "The Industrial Revolution" 1996 The Historical Journal 535-543

CIPC Second Quarter Performance Report

Companies and Intellectual Property Commission Second Quarter Performance Report 2018/2019 (CIPC Pretoria 2018)

Davies 2011 CLSR

Davies CR "An Evolutionary Step in Intellectual Property Rights - Artificial Intelligence and Intellectual Property" 2011 CLSR 601-619

De Koker and Du Plessis 2020 SAJIM

De Koker LT and Du Plessis T "Research as a Service Offering of Knowledge Management Firms in the Fourth Industrial Revolution" 2020 SAJIM 1-8 https://sajim.co.za/index.php/sajim/article/view/1178/1636

Deshpande and Kamath 2020 JIPLP

Deshpande $\mathrm{R}$ and Kamath K "Patentability of Inventions Created by Al: The DABUS Claims from an Indian Perspective" 2020 JIPLP 879-889

Doran and Webster 2019 World Patent Information

Doran P and Webster E "Who Influences USPTO Patent Examiners?" 2019 World Patent Information 39-42 
Drahos and Braithwaite Information Feudalism

Drahos $\mathrm{P}$ and Braithwaite J Information Feudalism: Who Owns the Knowledge Economy? (Earthscan London 2002)

Editor 2016 World Patent Information

Editor "Artificial Intelligence and IP" 2016 World Patent Information A1-A3

Fix the Patent Laws Patent Barriers to Medicine Access

Fix the Patent Laws Patent Barriers to Medicine Access in South Africa: A Case for Patent Law Reform (Fix the Patent Laws Campaign Pretoria 2012)

Flint 2020 Bus L Rev

Flint D "Intelligence: The Artificial Way" 2020 Bus L Rev 151-152

Franka, Dalenogare and Ayala 2019 International Journal of Production Economics

Franka AG, Dalenogare LS and Ayala NF "Industry 4.0 Technologies: Implementation Patterns in Manufacturing Companies" 2019 International Journal of Production Economics 15-26

Genin and Zolkin 2021 World Patent Information

Genin BI and Zolkin DS "Similarity Search in Patents Databases. The Evaluation of the Seach Quality" 2021 World Patent Information 1-4

Gennatas, Chen and Giger Artificial Intelligence Medicine

Gennatas LED, Chen JH and Giger ML Artificial Intelligence Medicine: Technical Basis and Clinical Applications (Academic Press London 2020)

Giaglis 2018 Cyprus Review

Giaglis G "The Emerging Blockchain Revolution and its Implications for Cyprus" 2018 The Cyprus Review 157-158

Gravett 2020 PELJ

Gravett WH "Is the Dawn of the Robot Lawyer upon Us? The Fourth Industrial Revolution and the Future of Lawyers" 2020 PELJ 1-37

Grimaldi, Grecob and Cricelli 2021 Journal of Business Research

Grimaldi M, Grecob M and Cricelli M "A Framework of Intellectual Property Protection Strategies and Open Innovation" 2021 Journal of Business Research 156-164

Haggart "What is Intellectual Property?"

Haggart B "What is Intellectual Property?" in Callahan M and Rogers J (eds) A Critical Guide to Intellectual Property (ZED Books London 2017) ch 1 
Hattenbach and Glucoft 2015 STLR

Hattenbach B and Glucoft $J$ "Patents in an Era of Infinite Monkeys and Artificial Intelligence" 2015 STLR 32-51

Hattenbach and Snyder 2018 Colombia Science and Technology Law Review

Hattenbach B and Snyder S "Rethinking the Mental Steps Doctrine and Other Barriers to Patentability of Artificial Intelligence" 2018 The Colombia Science and Technology Law Review 313-338

Hestermeyer Human Rights and the WTO

Hestermeyer H Human Rights and the WTO: The Case of Patents and Access to Medicines (Oxford University Press New York 2008)

Hill 2014 Expert Opinion on Therapeutic Patents

Hill JE "Changes to Intellectual Property Policy in South Africa: Putting a Stop to Evergreening?" 2014 Expert Opinion on Therapeutic Patents 839843

Ireland, Hoskisson and Hitt Understanding Business Strategy Ireland RD, Hoskisson RE and Hitt MA Understanding Business Strategy: Concepts Plus $3^{\text {rd }}$ ed (South-Western Cengage Learning Mason 2012)

Kankanala 2012 JIPR

Kankanala KC "Business Value from Intellectual Property" 2012 JIPR 369373

Khotha and Stern 2005 SAJIM Khotha IA and Stern A "Leveraging Intellectual Property for Strategic Advantage in Product Development" 2005 SAJIM 1-14 https://sajim.co.za/index.php/sajim/article/view/285/275

Kidd 2020 Australasian Biotechnology

Kidd M "Using Al to Invent Therapeutics: Should Artificial Intelligence be Recognised for Inventive Activity?" 2020 Australasian Biotechnology 40-42

Klopper et al Law of Intellectual Property

Klopper $\mathrm{H}$ et al Law of Intellectual Property in South Africa (LexisNexis Durban 2011) 
Lau, Kong and Baark 2012 Journal of Science and Technology Policy in China

Lau AKW; Kong SLS and Baark E "Research Advancement on Intellectual Property Strategy Implications for China under Globalization" 2012 Journal of Science and Technology Policy in China 49-67

Mathur 2020 JIPR

Mathur A "A Reflection upon the Digital Copyright Laws in India" 2020 JIPR 5-14

McClure 2015 Chapman L Rev

McClure ID "From a Patent Market for Lemons to a Marketplace for Patents: Benchmarking IP in its Evolution to Asset Class Status" 2015 Chapman L Rev 759-797

Mercurio and Tyagi 2010 Minn J Int'l L

Mercurio B and Tyagi M "Treaty Interpretation in WTO Dispute Settlement: The Outstanding Question of the Legality of Local Working Requirements" 2010 Minn J Int'I L 275-326

Mueller Introduction to Patent Law

Mueller JM An Introduction to Patent Law (Aspen London 2006)

Naicker 2016 De Rebus

Naicker Y "Optional Features in a Patent Claim" 2016 De Rebus 48

Ncube Science, Technology \& Innovation and Intellectual Property

Ncube CB Science, Technology \& Innovation and Intellectual Property: Leveraging Openness for Sustainable Development in Africa (Juta Cape Town 2021)

Ndlovu 2014 Speculum Juris

Ndlovu L "The WTO TRIPS Agreement and Access to Medicines in South Africa Twenty Years into Democracy" 2014 Speculum Juris 70-100

Ndlovu 2015 PELJ

Ndlovu L "Lessons for the SADC from the Indian Case of Novartis $A G V$ Union of India" 2015 PELJ 783-815

Ocen et al 2020 Journal of Engineering

Ocen GG et al "Exponential Disruptive Technologies and the Required Skills of Industry 4.0" 2020 Journal of Engineering 1-22 
Oloko 2016 CLB

Oloko TO "An Examination of Article 27 of the TRIPS Agreement in relation to the Provisions on Patentable Subject Matter under the PDA in Nigeria" 2016 CLB 236-260

Panch, Szolovits and Atun 2018 Journal of Global Health

Panch T, Szolovits $P$ and Atun R "Artificial Intelligence, Machine Learning and Health Systems" 2018 Journal of Global Health 1-8 https://www.ncbi.nlm.nih.gov/pmc/articles/PMC6199467/

Peredy and Laki 2020 IJEMS

Peredy Z and Laki B "Possible Ways of IP Commercialisation in the European Higher Education Ecosystem" 2020 IJEMS 56-74

Perkmann, Tartari and Mckelvey 2013 Research Policy

Perkmann M; Tartari V and Mckelvey M "Academic Engagement and Commercialisation: A Review of the Literature on University-Industry Relations" 2013 Research Policy 423-442

Ramadoss, Alam and Seeram 2018 IJES

Ramadoss TS, Alam H and Seeram R "Artificial Intelligence and Internet of Things Enabled Circular Economy" 2018 IJES 55-63

Razak, Murray and Roberts 2014 Knowledge and Process Management Razak AA, Murray PA and Roberts D "Open Innovation in Universities: The Relationship between Innovation and Commercialisation" 2014 Knowledge and Process Management 260-269

Reddy 2013 JIPR

Reddy GB "Local Working of Patents: Law and Implementation in India" 2013 JIPR 15-27

Ryder and Madhavan Intellectual Property and Business

Ryder RD and Madhavan A Intellectual Property and Business: The Power of Intangible Assets (Sage New Delhi 2014)

Schwab Fourth Industrial Revolution

Schwab K The Fourth Industrial Revolution (World Economic Forum Geneva 2016)

Sengupta Biological Drugs

Sengupta A Biological Drugs: Challenges to Access (Third World Network Penang 2018) 
Singh and Sachdev 2014 ICROIT

Singh H and Sachdev A "The Quantum Way of Cloud Computing" 2014 ICROIT 397-400

Stewart Intellectual Capital

Stewart T Intellectual Capital, The New Wealth of Organizations (Doubleday New York 1997)

Sullivan $1999 J K M$

Sullivan PH "Profiting from Intellectual Capital" 1999 JKM 132-142

Sullivan and Harrison 2008 WIPO Magazine

Sullivan P and Harrison S "IP and Business: Managing IP as a Set of Business Assets" 2008 WIPO Magazine 1-4

Surden 2014 Wash L Rev

Surden H "Machine Learning and Law" 2014 Wash L Rev 87-115

Taubman, Wager and Watal Handbook on the WTO TRIPS Agreement

Taubman A, Wager $\mathrm{H}$ and Watal $\mathrm{J} A$ Handbook on the WTO TRIPS Agreement (Cambridge University Press Cambridge 2012)

Tomlinson et al 2019 SAMJ

Tomlinson C et al "How Patent Law Reform can Improve Affordability and Accessibility of Medicines in South Africa: Four Medicine Case Studies" 2019 SAMJ 387-391

Van der Merwe "Law of Patents"

Van der Merwe A "The Law of Patents" in Geyer S et al (eds) Law of Intellectual Property in South Africa (LexisNexis Durban 2016) 359-424

Van der Walt and Pienaar Introduction to the Law of Property

Van der Walt AJ and Pienaar GJ Introduction to the Law of Property (Juta Cape Town 2016)

Wang, Phillips and Yang 2020 Journal of Business Research Wang Y, Phillips $F$ and Yang C "Bridging Innovation and Commercialization to Create Value: An Open Innovation Study" 2020 Journal of Business Research 255-266

Watal "Patents"

Watal J "Patents: An Indian Perspective" in Watal $J$ and Taubman A (eds) The Making of the TRIPS Agreement: Personal Insights from the Uruguay Round Negotiations (WTO OMC Geneva 2016) 295-320 
Xu, David and Kim 2018 International Journal of Financial Research

$\mathrm{Xu} \mathrm{M}$; David JM and Kim SH "The Fourth Industrial Revolution: Opportunities and Challenges" 2018 International Journal of Financial Research 90-95

Zhao 2017 QMJIP

Zhao $Y$ "Intellectual Property Protection in Outer Space: Reconciling Territoriality of Intellectual Property with Non-Territoriality in Outer Space" 2017 QMJIP 137-155

\section{Case law}

Ascendis Animal Health (Pty) Limited $v$ Merck Sharpe Dohme Corporation 20201 SA 327 (CC)

Buckman Laboratories (Pty) Ltd v Bromine Compounds Ltd 2008 ZASCA 37 (28 March 2008)

Coflexip SA v Schlumberger Logelco Incorporated 2001 BIP 1 (CP)

Darcy v Allen 72 Eng Rep 830 (1603)

Deutsche Gesellschaft Fur Schadlingsbekampfung MB v Coopers (South Africa) (Pty) Ltd 1973 BP 447 (CP)

Ensign Bickford v AECl 1998 BIP 271 (SCA)

Ensign Bickford v AECl 1999 1 SA 70 SCA

Gentiruco AG v Firestone SA (Pty) Ltd 1971 BP 58 (A)

Gentiruco AG v Firestone SA (Pty) Ltd 19721 SA 589 (A)

lan Fraser-Johnson v Gl Marketing CC 1993 BP 461 (CP)

Letraset Ltd $v$ Helios Ltd 1972 BP 243 (A)

Moroney v West Rand Engineering Works (Pty) Ltd 1970 BP 452 (T)

Netlon v Pacnet 19773 SA 840 (A)

Roman Roller CC v Speedmark Holdings (Pty) Ltd 1995 BP 199 (A)

Roman Roller CC v Speedmark Holdings (Pty) Ltd 19961 SA 405 (A) 
Selas Corporation of America $v$ The Electric Furnace Company 1982 BP $442(\mathrm{~A})$

Vernon Hugh Bowman v Monsanto Company et al 569 US 278 (2013)

\section{Legislation}

Joint Resolution No 118/2012, 546/2012 and 107/2012 (Ministry of Industry, Ministry of Health and National Institute for Industrial Property) of 8 May 2012 (Argentina)

Patents Act, 1791 (France)

Patents Act 9 of 1916 (South Africa)

Patents Act 37 of 1952 (South Africa)

Patent Act 35 USC § 1295 (2012) (United States)

Patents Act 39 of 1970 (India)

Patents Act 57 of 1978 (South Africa)

Patent Statute of 19 March 1474 (Venetia)

Statute of Monopolies, 1623, 21 Jac 1, c 3 (England)

International Instruments

Agreement on Trade-Related Aspects of Intellectual Property Rights (1994)

Berne Convention for the Protection of Literary and Artistic Works, September 9, 1886, as revised at Stockholm on July 14, 1967828 UNTS 221

Patent Cooperation Treaty (1970)

Internet sources

Andersen et al 2018 https://www.accessnow.org/cms/assets /uploads/2018/11/Al-and-Human-Rights.pdf

Andersen L et al 2018 Human Rights in the Age of Artificial Intelligence https://www.accessnow.org/cms/assets/uploads/2018/11/Al-and-HumanRights.pdf accessed 30 May 2021 
Baker 2019 https://www.bu.edu/gdp/files/2020/05/ARIPO-Member-Statesobligations-and-flexibilities-under-the-WTO-TRIPS-Agreement-March2019.pdf

Baker BK 2019 A Full Description of WTO TRIPS Flexibilities Available to ARIPO Member States and a Critiques of ARIPO's Comparative Study Analyzing and Making Recommendations Concerning those Flexibilities https://www.bu.edu/gdp/files/2020/05/ARIPO-Member-States-obligationsand-flexibilities-under-the-WTO-TRIPS-Agreement-March-2019.pdf accessed 2 February 2021

CIPC 2018 https://www.facebook.com/theCIPC/posts/patent-examinersare-properly-and-regularly-trained-by-world-intellectual-

proper/2173025269582643/

Companies and Intellectual Property Commission 2018 Facebook Page Post of 18 August 2018 https://www.facebook.com/theCIPC/posts/patentexaminers-are-properly-and-regularly-trained-by-world-intellectualproper/2173025269582643/ accessed 1 February 2020

CIPC 2021 https://iponline.cipc.co.za/

Companies and Intellectual Property Commission 2021 CIPC Intellectual Property Online https://iponline.cipc.co.za/ accessed 1 February 2021

Department of Communications and Digital Technologies 2020 https://www.gov.za/sites/default/files/gcis_document/202010/43834gen59 1.pdf

Department of Communications and Digital Technologies 2020 Report of the Presidential Commission on the 4th Industrial Revolution (PC4IR) https://www.gov.za/sites/default/files/gcis_document/202010/43834gen59 1.pdf accessed 1 June 2021

DTI $2018 \quad$ https://www.gov.za/sites/default/files/gcis_document /201808/ippolicy2018-phasei.pdf

Department of Trade and Industry 2018 Intellectual Property Policy of the Republic of South Africa Phase I https://www.gov.za/sites/ default/files/gcis_document/201808/ippolicy2018-phasei.pdf accessed 2 February 2020

EPO $2020 \quad$ https://register.epo.org/application?documentld =E4B63OBI2076498\& \&umber $=E P 18275174 \&$ Ing $=e n$

European Patent Office 2020 Decision Issued on 27 January 2020 https://register.epo.org/application?documentld=E4B63OBI2076498\&num ber=EP18275174\&Ing=en accessed 13 January 2021 
Johnson and Johnson 1957 https://iponline.cipc.co.za/iponlineTemp/ patents/65293_20210201185914NI.pdf Johnson and Johnson 1957 Absorbent Cotton Balls and Method and Apparatus for Making the Same https:/iponline.cipc.co.za/ iponlineTemp/patents/65293_20210201185914NI.pdf accessed 30 May 2021

Kalanje 2017 https://iettn.ieee-ies.org/role-intellectual-property-innovationnew-product-development/

Kalanje CM 2017 The Role of Intellectual Property in Innovation and New Product Development https://iettn.ieee-ies.org/role-intellectual-propertyinnovation-new-product-development/ accessed 21 January 2021

Marwala 2019 https://youtu.be/Ss68_JZlwL8

Marwala T 2019 Prof Tshilidzi Marwala, Vice Chancellor and Principal University of Johannesburg Presentation on the 4th Industrial Revolution and Society Hosted by the University of Venda - Part 1 https://youtu.be/Ss68_JZlwL8 accessed 24 January 2020

Stanford University 2016 https:/ai100.stanford.edu/sites/g/files/ sbiybj9861/f/ai100report10032016fnl_singles.pdf

Stanford University 2016 Artificial Intelligence and Life in 2030: One Hundred Year Study on Artificial Intelligence https://ai100.stanford.edu/ sites/g/files/sbiybj9861/f/ai100report10032016fnl_singles.pdf accessed 13 December 2020

Tronson 2020 https://www.stlgip.com/wp-content/uploads/2020/04/ USPTO_Al_as_Inventor-r.pdf

Tronson S 2020 USPTO Joins EPO in Rejecting Al as Inventor https://www.stlgip.com/wp-content/uploads/2020/04/USPTO_AI_as_ Inventor-r.pdf accessed 13 January 2020

UKIPO 2019 https://www.ipo.gov.uk/p-challenge-decision-results/pchallenge-decision-results-bl?BL_Number=O/741/19

United Kingdom Intellectual Property Office 2019 Patent Decision of 4 December 2019 https://www.ipo.gov.uk/p-challenge-decision-results/pchallenge-decision-results-bl?BL_Number=O/741/19 accessed 13 January 2020

USPTO 2021 https://www.uspto.gov/patents/search

United States Patent and Trademark Office 2021 Search for Patents https://www.uspto.gov/patents/search accessed 3 February 2021 
USPTO 2021 http://patft.uspto.gov/netacgi/nph-Parser?Sect1=PTO2\& Sect2=HITOFF\&u=\%2Fnetahtml\%2FPTO\%2Fsearchadv. htm\& $=5 \& p=1 \& f=G \& l=50 \& d=P T X T \& S 1=$ (covid $19+$ AND+vaccine) $\& O S=$ covid-19+and+vaccine $\& R S=$ (covid19+AND+vaccine)

United States Patent and Trademark Office 2021 Search for Covid-19 and Vaccine http://patft.uspto.gov/netacgi/nph-Parser?Sect1=PTO2\&Sect2= HITOFF\&U=\%2Fnetahtml\%2FPTO\%2Fsearchadv. htm \& $r=5 \& p=1 \& \mathrm{f}=\mathrm{G} \& \mathrm{l}=50 \& \mathrm{~d}=\mathrm{PTXT} \& S 1=$ (covid $19+$ AND+vaccine) $\& O S=$ covid-19+and+vaccine $\& S=$ (covid19+AND+vaccine) accessed 3 February 2021

\section{List of Abbreviations}

4IR

Al

ARIPO

Bus L Rev

Chapman L Rev

CIPC

CLB

CLSR

EPO

ICROIT

IJEMS

IJES

IP

IPR

JEMS

JIPLP

JIPR

JKM

JLERI
Fourth Industrial Revolution

artificial intelligence

African Regional Industrial Property

Organisation

Business Law Review

Chapman Law Review

Companies and Intellectual Property

Commission

Commonwealth Law Bulletin

Computer Law and Security Review

European Patent Office

International Conference on Reliability

Optimization and Information Technology

International Journal of Engineering and Management Sciences

International Journal of Engineering and

Science

intellectual property

intellectual property right

Journal of Economics and Management

Strategy

Journal of Intellectual Property Law and Practice

Journal of Intellectual Property Rights

Journal of Knowledge Management

Journal of Legal, Ethical and Regulatory Issues 
Minn J Int'I L

PELJ

QMJIP

SAJIM

SAMJ

Saudi J Humanities Soc Sci

STLR

Technol Forecast

Change

TRIPS Agreement

UC Davis L Rev

UKIPO

USPTO

Wash L Rev

WIPO

WTO
Minnesota Journal of International Law

Potchefstroom Electronic Law Journal

Queen Mary Journal of Intellectual Property

South African Journal of Information Management

South African Medical Journal

Saudi Journal of Humanities and Social Sciences

Stanford Technology Law Review

Soc Technological Forecasting and Social Change

Agreement on Trade-Related Aspects of Intellectual Property Rights (1994)

University of California, Davis, Law Review

United Kingdom Intellectual Property Office

United States Patent and Trademark

Office

Washington Law Review

World Intellectual Property Organization

World Trade Organization 